\title{
20 Predicados complexos numa perspetiva comparativa
}

\begin{abstract}
Neste capítulo apresentam-se aspetos sintático-semânticos caracterizadores dos predicados complexos, entendidos como sequências de dois (ou mais) verbos que participam numa relação de complementação infinitiva e que, em determinados contextos, formam uma unidade sintático-semântica. Numa perspetiva comparativa, com dados de outras línguas e de diferentes variedades de português, são identificadas as características gerais definidoras de predicados complexos (verbais) em português europeu e distinguem-se duas construções, designadas por reestruturação e fazer-Infinitivo. Para cada uma destas construções, são apresentadas propriedades diferenciadoras e são identificados elementos dos diferentes grupos de verbos que podem ocorrer em predicados complexos.
\end{abstract}

Keywords: construções infinitivas, predicado complexo sintático, construção de reestruturação, construção fazer-Inf

\section{Introdução}

Em português europeu, como noutras línguas românicas, existem verbos que selecionam como complemento orações (completivas) de infinitivo não flexionado e que manifestam um comportamento sintático particular, podendo ocorrer (i) em construções de complementação típicas, mantendo as suas propriedades de verbos principais, como nos exemplos (1a) e (1b), e (ii) em construções em que formam uma unidade sintática com o verbo do complemento infinitivo, exibindo um comportamento próximo do dos verbos auxiliares, no sentido em que o seu complemento é transparente para determinados processos sintáticos que deveriam aplicar-se internamente a esse complemento, como no exemplo (1c). Em particular, neste exemplo, o clítico a realizase em adjacência ao verbo que seleciona a oração infinitiva (querer), e não ao verbo que o seleciona (interromper), construção que se designa como subida de clítico, uma vez que o pronome se realiza numa posição mais alta na frase do que a esperada, que seria a de adjacência ao verbo de que depende semântica e/ou sintaticamente - o verbo encaixado.

(1) a. O professor quer [que os alunos não interrompam a exposição].

b. O professor não quer [interrompê-la].

c. O professor não a [quer interromper]. 
$\mathrm{Na}$ literatura sobre o assunto, a sequência formada pelos dois (ou mais) verbos nesta última construção tem sido designada como predicado complexo, termo introduzido por Burzio (1986). ${ }^{1}$

Um dos marcos fundamentais no estudo dos predicados complexos é o trabalho de Kayne (1975), sobre os verbos causativos do francês. ${ }^{2}$ Nesse trabalho, o autor mostra que verbos pertencentes a domínios frásicos distintos (a frase matriz e a frase encaixada) podem comportar-se como uma unidade sintática face a determinados fenómenos sintáticos, como a colocação dos pronomes pessoais átonos (clíticos) dependentes do verbo do complemento infinitivo: em certas construções causativas do francês, tais clíticos realizam-se obrigatoriamente em adjacência ao verbo superior, o verbo causativo. Esta subida de clítico encontra-se ilustrada em (2b-c), em contraste com (2d-e). (Sobre colocação de clíticos em português, cf. 15 A colocação dos pronomes clíticos em sincronia e diacronia).

(2) a. Elle fera manger ce gâteau à Jean.

b. Elle le fera manger à Jean.

c. Elle lui fera manger ce gâteau.

d. *Elle fera le manger à Jean.

e. *Elle fera lui manger ce gâteau.

(Kayne 1975, 255-256)

Tendo em consideração dados do italiano, Rizzi (1976; 1978; 1982) considera um outro conjunto de verbos (como os equivalentes de querer, poder, ir e vir, entre outros), cujos membros também formam uma unidade sintática com o verbo do seu complemento infinitivo. Tal como acontece com os verbos causativos do francês, estudados por Kayne, com alguns verbos do italiano que pertencem às classes descritas por Rizzi, também se verifica subida de clítico (cf. (3a)), embora opcionalmente (cf. (3b)):

(3) a. Piero ti verrà a parlare di parapsicologia.

b. Piero verrà a parlarti di parapsicologia.

(Rizzi 1982, 1)

\footnotetext{
${ }^{1}$ Num sentido mais lato, o termo predicado complexo aparece também por vezes associado a uma maior diversidade de outras sequências, podendo envolver um verbo e um elemento predicador de outra categoria, como um nome, um adjetivo, uma partícula, não necessariamente numa relação de complementação (cf. e.g. Duarte 2003, Svenonius 2008). Usamos aqui, na esteira de Burzio 1986, uma noção mais restritiva de predicado complexo.

${ }^{2}$ A ideia de que existem dois tipos de complementos infinitivos, um que constitui um domínio frásico independente e outro em que se observam efeitos de transparência que anulam a autonomia do mesmo, pode encontrar-se já num texto de Gunnar Bech, dos anos 50, para o alemão (Bech ${ }^{1}$ 1955-1957).
} 
Embora o termo predicado complexo seja usado para referir globalmente construções como as exemplificadas em (2a-c) e em (3a), existem algumas diferenças entre elas que motivam diferentes designações: no caso das construções com verbos causativos (e percetivos, como se verá adiante), usaremos, na linha de Kayne (1975), o termo fazer-Inf e, para as construções idênticas às do italiano em (3a), o termo reestruturação, como em Rizzi (1976; 1978; 1982). Tal como nas línguas acima referidas, as duas construções estão disponíveis em português (cf. (4) para a construção fazer-Inf e (5c), ou (1c), para a construção de reestruturação):

(4) a. Ela mandou comer o bolo ao João.

b. Ela mandou-o comer ao João. $[o=o$ bolo $]$

c. Ela mandou-lhe comer o bolo. [lhe = ao João]

(5) a. O João não quis conhecer a Marta.

b. O João não quis conhecê-la. [ [la=a Marta]

c. O João não a quis conhecer. [ $a=a$ Marta $]$

A possibilidade de os clíticos ocorrerem em adjacência ao verbo superior, ilustrada em (4b-c) e em (5c), bem como outras propriedades que revelam que o complemento infinitivo selecionado pelos verbos de reestruturação (e também pelos causativos e percetivos) é transparente para determinados fenómenos sintáticos, levou muitos gramáticos luso-brasileiros a considerar que alguns destes verbos são auxiliares (veja-se, em particular, Soares Barbosa 1822; Said Ali 1908; 1931; Epiphanio Silva Dias 1917; Bechara ${ }^{1} 1963,{ }^{37} 1999$; Cunha/Cintra 1984). Contudo, como vários autores têm assinalado (para o português europeu, ver Gonçalves 2001) tais verbos não devem ser classificados como auxiliares. O facto de, em alguns casos, o comportamento dos verbos de reestruturação se aproximar do dos auxiliares típicos tem sido explicado por mecanismos que criam efeitos de transparência sintática semelhantes aos que se observam em sequências de verbo auxiliar-verbo principal, ou seja, que dão origem a um elevado grau de sintatização entre os dois verbos do predicado complexo. É este segundo tipo de abordagem que se apresentará no presente capítulo. ${ }^{3}$

\footnotetext{
${ }^{3}$ Sobre a distinção entre verbos de reestruturação e os auxiliares típicos, veja-se a secção 3.2.2.
} 


\section{A identificação de predicados complexos}

\subsection{Propriedades dos predicados complexos sintáticos: os estudos seminais}

Para dar conta do comportamento dos verbos que permitem a formação de predicados complexos, têm sido propostas análises nem sempre coincidentes. Por exemplo, uma das questões mais debatidas na literatura é a de saber se as construções desta natureza são bioracionais (isto é, se o complemento infinitivo mantém a sua autonomia sintática) ou monoracionais (caso em que a fronteira frásica que corresponde ao complemento infinitivo é, de certa forma, inexistente). No entanto, é consensualmente aceite que um predicado complexo consiste numa sequência de dois ou mais elementos (verbos, no caso que nos ocupa neste capítulo) que apresentam um forte grau de coesão sintático-semântica.

No seu trabalho de 1975, Kayne analisa os verbos causativos do francês (e.g. faire seguido de complemento infinitivo) numa construção que designa como «faire-Infinitif» e na qual o constituinte que, aparentemente, corresponde ao sujeito do verbo no infinitivo apresenta as seguintes propriedades:

(i) ocorre após a sequência <verbo causativo-verbo infinitivo> (cf. (6a) e (7a));

(ii) é substituível por um pronome clítico acusativo (como le ou, em português, $o$ ) ou dativo (como lui, ou lhe em português), dependendo das propriedades sintáticas do verbo infinitivo; assim, contrariamente ao que acontece no caso dos sujeitos típicos, que apenas podem ser substituídos pelo pronome pessoal na sua forma nominativa (como ele), na construção em apreço o pronome assume a forma acusativa, típica do objeto direto, no contexto de verbos intransitivos (cf. (6b)), e a forma dativa, típica do objeto indireto, no contexto de verbos transitivos (cf. (7b));

(iii) quando assume a forma clítica, ocorre obrigatoriamente em adjacência ao verbo causativo e não ao verbo de que depende semanticamente (o infinitivo) - i.e. existe subida de clítico -, como se conclui da agramaticalidade de (6c) e (7c).

(6) a. Elle fera partir ses amis.

(Kayne ${ }^{1} 1975,1977,255$, ex. (1))

b. Elle les fera partir.

c. *Elle fera les partir.

(7) a. Elle fera manger ce gâteau à Jean.

(Kayne ${ }^{1} 1975,1977,255$, ex. (1))

b. Elle lui fera manger ce gâteau.

c. *Elle fera lui manger ce gâteau.

O facto de o alegado sujeito do verbo infinitivo corresponder a formas pronominais que não são características dos verdadeiros sujeitos e de os clíticos se realizarem em 
adjacência ao verbo causativo e não ao verbo que os seleciona constituem argumentos empíricos para a classificação da sequência de verbos como predicado complexo. Na realidade, o complemento infinitivo não se apresenta como um domínio autónomo, visto que constituintes desse domínio podem ser realizados em posições relacionadas com o primeiro verbo.

Largamente inspirado no estudo de Kayne (1975), ainda que apresente uma análise distinta, Burzio (1986) mostra que a mesma construção se encontra disponível com os verbos causativos do italiano (fare 'fazer'/'mandar' e lasciare 'deixar') e que, nesta língua, também os verbos percetivos (vedere 'ver', sentire 'ouvir') podem desencadear a formação de um predicado complexo, embora em alguns aspetos distinto daquele em que ocorre um verbo causativo.

No estudo de Rizzi (1982), que constitui uma versão revista de um trabalho inaugural do mesmo autor, datado de 1978, é considerado um outro tipo de predicados complexos em italiano, que resultam de um processo sintático a que o autor chama reestruturação. Em italiano, a formação deste tipo de predicados complexos é desencadeada por alguns verbos que o autor classifica como modais (e.g. potere 'poder', volere 'querer'), aspetuais (e.g. continuare 'continuar', cominciare 'começar') e de movimento (e.g. andare 'ir', venire 'vir') e que apresentam comportamentos sintáticos distintos dos de outros verbos que pertencem às mesmas classes, selecionando igualmente complementos infinitivos.

Em primeiro lugar, com alguns verbos das referidas classes, os clíticos dependentes do verbo do complemento infinitivo (que designaremos como verbo encaixado) podem ocupar uma de duas posições: em adjacência a este verbo ou em adjacência ao verbo que seleciona a completiva (o verbo matriz). Esta última posição ilustra a já referida construção de subida de clítico. Os exemplos em (8) e (9) apresentam o contraste entre os verbos do italiano relativamente à subida de clítico (dados retirados de Rizzi 1982):

(8) a. Piero verrà a parlarti di parapsicologia.

b. Piero ti verrà a parlare di parapsicologia.

(9) a. Piero deciderà di parlarti de parapsicologia.

b. *Piero ti deciderà di parlare di parapsicologia.

De acordo com Rizzi (1982), a subida de clítico em (8b) é uma propriedade caracterizadora dos predicados complexos de reestruturação. A ideia é que, se o complemento infinitivo constituir um domínio totalmente autónomo, qualquer processo 
que envolva os elementos desse domínio, como a posição relativa entre o verbo e os clíticos que dele dependem, só pode operar internamente ao mesmo, como acontece em (9). Neste caso, não se verifica reestruturação. Assim, tendo em conta os dados em (8)-(9), Rizzi conclui que venire desencadeia reestruturação, mas decidere não.

A segunda propriedade distintiva dos verbos que admitem reestruturação em italiano é, segundo Rizzi (1982), a possibilidade de o objeto direto do verbo infinitivo em frases ativas ser realizado como sujeito em frases passivas pronominais. ${ }^{4}$ Assim, como acontece no caso da subida de clítico, os verbos que selecionam complementos infinitivos distribuem-se por duas classes, como mostra o contraste entre (10b) e (11b) (dados de Rizzi 1982):

(10) a. Si vuole vendere queste case a caro prezzo.

b. Queste case si vogliono vendere a caro prezzo.

(11) a. Si è promesso di costruire le nuove case popolari entro un anno.

b. *Le nuove case popolari si sono promesse di costruire entro un anno.

O constituinte queste case, correspondente ao objeto direto do verbo no infinitivo na frase ativa em (10a), realiza-se, na passiva pronominal em (10b), como sujeito do verbo matriz, volere. Podemos dizer que este constituinte, selecionado pelo verbo da frase encaixada, como objeto, se move para uma posição mais alta na frase - a de sujeito da frase matriz, designando-se esta construção como movimento longo de objeto (Rizzi 1978; 1982). Como se verifica pela agramaticalidade de (11b), nem todos os verbos que selecionam complementos infinitivos admitem esta construção. A conclusão de Rizzi (1982) é a de que o movimento longo de objeto só se verifica em contextos de reestruturação, visto que só neste caso a oração infinitiva é, de uma forma que

\footnotetext{
${ }^{4}$ Nas orações passivas pronominais ocorre sempre o clítico se, sem que se realize qualquer verbo auxiliar. Considerem-se os exemplos em (i), retirados de Duarte (2013, 444 e 445):

(i) a. As obras mais recentes publicaram-se numa editora espanhola para garantir maiores tiragens.

b. Já se publicaram em português todos os romances de Salman Rushdie.

Nestas orações, o verbo ocorre sempre na 3 . $^{\text {a }}$ pessoa e concorda em número e pessoa com um constituinte que, na oração ativa, corresponde ao seu objeto (no caso dos exemplos em (i), os constituintes as obras mais recentes e todos os romances de Salman Rushdie). Assim, o objeto do verbo na oração ativa realiza-se como sujeito na oração passiva pronominal, como acontece nas passivas em que ocorre o auxiliar ser:
}

(ii) a. As obras mais recentes foram publicadas numa editora espanhola para garantir maiores tiragens. b. Já foram publicados em português todos os romances de Salman Rushdie. 
caracterizaremos adiante, transparente, permitindo que elementos que pertencem ao domínio do verbo encaixado se realizem no domínio do verbo matriz.

Finalmente, Rizzi (1982) nota que a escolha do auxiliar que ocorre nos tempos compostos é uma outra propriedade que permite caracterizar distintivamente os verbos de reestruturação do italiano. Esta língua, tal como o francês, dispõe de dois auxiliares de tempos compostos, avere (em português, ter) e essere (em português, ser), cuja distribuição é prevista a partir das propriedades do verbo principal. Assim, em frases simples, um verbo como volere seleciona o auxiliar avere, ao passo que um verbo como tornare seleciona o auxiliar essere:

(12) a. Gianni ha voluto i libri.

b. *Gianni è voluto i libri.

(13) a. Gianni è tornato a casa.

b. *Gianni ha tornato a casa.

Em frases complexas, alguns verbos que selecionam avere podem também coocorrer com essere, desde que seja este o auxiliar selecionado pelo verbo encaixado. É o que acontece em frases em que a oração infinitiva é complemento de volere, como se ilustra em (14); porém, no contexto do verbo promettere, o único auxiliar possível é avere, mesmo que o verbo encaixado selecione essere, como se conclui da agramaticalidade de (15b):

(14) a. Gianni ha voluto tornare a casa.

b. Gianni è voluto tornare a casa.

(15) a. Mario ha promesso di tornare a casa.

b. *Mario è promesso di tornare a casa.

O facto de em (14) ser possível a ocorrência do auxiliar selecionado pelo verbo encaixado constitui, segundo Rizzi (1982), uma característica de um predicado complexo, uma vez que as propriedades desse verbo podem determinar alterações na frase matriz, como se não existisse uma fronteira frásica. Por essa razão, nos casos em que há mudança do auxiliar, é obrigatória a subida de clítico, como se observa em (16cd):

(16) a. Gianni ha voluto andarci.

b. *Gianni ci ha voluto andare. 
c. Gianni ci è voluto andare.

d. *Gianni è voluto andarci.

Nos exemplos que nos têm vindo a ocupar, a formação do predicado complexo tem apenas efeitos sintáticos. No entanto, em algumas línguas, nomeadamente as polissintéticas, ${ }^{5}$ de raiz não indo-europeia, como o mowhak, ou o chichewa, a complexidade deste tipo de predicados manifesta-se não só na sintaxe, mas também na morfologia, já que os elementos que constituem o predicado complexo formam uma unidade morfológica. Nestes casos, um dos elementos do predicado complexo é um afixo, o que obriga à formação da unidade morfológica, impede a ocorrência de material lexical entre os dois membros do predicado e resulta num único domínio frásico, propriedades visíveis no exemplo (17), do chichewa:

(17) Mtsikana anau-gw-ets-a mtsuko. rapariga FLEX-cair-fez-ASP cântaro 'A rapariga fez cair o cântaro.'

(Baker 1988, 148)

No entanto, como Baker (1996) salienta, esta característica não deve fazer parte da definição dos predicados complexos, visto que, em línguas analíticas, como o português, o francês ou o italiano, os membros do predicado complexo preservam a sua autonomia morfológica, sendo mesmo possível inserir material lexical entre eles, como se ilustra em (18) para o português:

(18) a. Ela mandou-o $\underline{\log 0}$ comer ao João.

b. Ele não a quis mesmo conhecer.

Em síntese, a partir dos estudos seminais de Kayne (1975), Rizzi (1978; 1982) e Burzio (1986), são normalmente tomadas como indicadoras da formação de predicados complexos, em sequências verbais introduzidas por verbos causativos (e.g. mandar), percetivos (e.g. ouvir) ou verbos de reestruturação, como querer e verbos modais (e.g. poder) e aspetuais (e.g. continuar), as seguintes propriedades sintáticas: (i) subida de

\footnotetext{
${ }^{5}$ Sapir $(1921,128)$ caracteriza as línguas polissintéticas da seguinte forma: «A polysynthetic language, as its name implies, is more than ordinarily synthetic. The elaboration of the word is extreme. Concepts which we should never dream of treating in a subordinate fashion are symbolized by derivational affixes or <symbolic> changes in the radical element, while the more abstract notions, including the syntactic relations, may also be conveyed by the word».
} 
clítico; (ii) movimento longo de objeto; e, (iii) em línguas que dispõem de mais do que um auxiliar para formação de tempos compostos, manifestação do auxiliar do verbo infinitivo em formas de tempo composto do predicado complexo. Em português europeu, os predicados complexos são, globalmente, caracterizados pelas propriedades (i) e (ii).

\subsection{Dois tipos de predicados complexos em português europeu}

Como afirmámos anteriormente, desde os primeiros estudos para o francês (Kayne 1975) e para o italiano (Rizzi 1978; 1982; Burzio 1986), tem sido demonstrado que, nas frases que integram um predicado complexo nas línguas românicas, um verbo que seleciona um complemento infinitivo constitui um núcleo sintática e semanticamente coeso com o verbo deste complemento. Dito de outra forma, os dois verbos manifestam um elevado grau de sintatização, o que determina que, em certos contextos, se comportem como se formassem uma unidade do ponto de vista sintático.

O termo complemento permite excluir, desde logo, os casos em que a oração infinitiva tem a função sintática de sujeito ou de adjunto (cf. (19) e (20)). Por sua vez, o termo infinitivo exclui os casos em que a oração selecionada pelo primeiro verbo, ainda que desempenhe a função sintática de complemento, é finita (ou seja, apresenta o verbo nos modos indicativo ou conjuntivo; cf. (21)); de facto, tomando, por agora, a subida de clítico como critério para identificação de um predicado complexo também para o português europeu, verifica-se que a mesma não opera nestes contextos:

(19) a. Não surpreendeu a Ana ter encontrado o Pedro.

b. Não surpreendeu a Ana tê-lo encontrado. $[(l) O=o$ Pedro $]$

c. *Não o surpreendeu a Ana ter encontrado.

(20) a. O João não quer sair sem ver $a$ Marta.

b. O João não quer sair sem a ver. [ $a=a$ Marta]

c. *O João não a quer sair sem ver.

(21) a. A Maria não quer que a Ana leia o livro.

b. A Maria não quer que a Ana o leia. [o=o livro]

c. *A Maria não o quer que a Ana leia.

A observação destes dados conduz à primeira generalização sobre os contextos em que um predicado complexo pode ocorrer, a saber, completivas de infinitivo. Numa língua que, como o português, dispõe de infinitivo flexionado, coloca-se, agora, uma segunda questão - a de saber se este é um contexto que legitima a formação de um predicado 
complexo. A resposta é negativa, como se conclui da agramaticalidade da subida do clítico em (22c):

(22) a. O presidente lamentou terem os polícias agredido os manifestantes.

b. O presidente lamentou terem-nos os polícias agredido. [ $(n) o s=$ os manifestantes $]$

c. ${ }^{*} \mathrm{O}$ presidente lamentou-os terem os polícias agredido.

Assim, a generalização acima deverá ser reformulada para o português europeu: os predicados complexos ocorrem exclusivamente em contextos de infinitivo não flexionado. São, assim, potenciais desencadeadores da formação de predicados complexos os verbos causativos e percetivos, os verbos de controlo e os verbos de elevação. ${ }^{6}$ Contudo, como acontece em italiano e em francês, o facto de um verbo pertencer a uma destas classes não garante a formação de um predicado complexo. Veja-se, neste sentido, o contraste entre (23) e (24), em que os verbos matriz (querer e prometer) pertencem ambos à classe dos verbos de controlo: ${ }^{7}$

(23) a. O treinador não quis contratar os jogadores desempregados.

b. O treinador não quis contratá-los.

c. O treinador não os quis contratar.

(24) a. O treinador não prometeu contratar os jogadores desempregados.

b. O treinador não prometeu contratá-los.

c. *O treinador não os prometeu contratar.

\footnotetext{
${ }^{6}$ Neste capítulo, assumimos as análises clássicas de controlo e de elevação (Chomsky 1981, entre outros). Assim, o termo controlo designa estruturas em que, quando o infinitivo não flexionado é usado na frase encaixada, o sujeito desta frase é nulo e tem um antecedente fixo na frase superior: o sujeito (em (i)), o objeto direto (em (ii)) ou o objeto indireto (em (iii)). Esta relação entre antecedente (na frase matriz) e sujeito nulo da frase encaixada é assinalada através de índices nos exemplos que se seguem.
}

(i) Os meninos ${ }_{i}$ querem $[-]_{i}$ comprar uma bicicleta.

(ii) Os pais obrigaram os meninos $\underline{x}_{i}$ a $[-]_{i}$ comer a sopa.

(iii) Os pais permitiram $\underline{\underline{\operatorname{aos} m e n i n o s}} i[-]_{i}$ chegar depois da meia-noite.

Por sua vez, o termo elevação designa estruturas em que um constituinte com uma função sintática na frase superior (nos casos que nos interessam neste capítulo, o sujeito) corresponde a um argumento do verbo da encaixada, posição a partir da qual foi movido, como em (iv):

(iv) a. Os meninos parecem [es menines] dormir.

b. Os meninos devem [өs menines] dormir.

Os verbos matriz que ocorrem na construção de controlo designam-se como verbos de controlo, os que ocorrem na construção de elevação, como verbos de elevação.

${ }^{7}$ Cf. também variação nas manifestações típicas de alguns destes verbos, mencionada na secção 2.3, adiante. 
A distribuição dos verbos que selecionam um complemento infinitivo por dois grupos (os verbos de controlo e os de elevação, que ocorrem na construção de reestruturação, e os verbos causativos e percetivos, que ocorrem na construção fazer-Inf) não é um traço inovador do português. Com efeito, os dados do italiano apresentados na secção anterior revelam um comportamento idêntico nesta língua. Interessa, portanto, verificar se as propriedades que caracterizam os predicados complexos em italiano se aplicam ao português.

O contraste que os exemplos (23) e (24) ilustram permite afirmar que a subida de clítico também opera em português europeu em contextos de reestruturação. Assim, tendo em conta esta propriedade, diríamos que o verbo querer, mas não o verbo prometer, é um verbo de reestruturação. ${ }^{8}$ Como se referiu a propósito dos dados do italiano, sendo a colocação do clítico um processo local (isto é, por defeito, o clítico associa-se ao verbo de que depende sintática e/ou semanticamente), espera-se que, em frases complexas, o clítico se realize junto do verbo encaixado, se dele depender. ${ }^{9}$ É isso que se observa em (24), no contexto do verbo prometer, mas não em (23), no contexto do verbo querer. Este contraste foi notado, para o português europeu, em Martins (1995) e em Gonçalves (1999).

\footnotetext{
${ }^{8}$ De acordo com Fiéis/Madeira (2012), existe uma gradação de aceitabilidade destas construções, que depende da presença de elementos proclisadores (ou seja, de elementos que desencadeiam a próclise e que, segundo as autoras, facilitam a subida de clítico) e do próprio tipo de clítico. Embora se verifique, efetivamente, alguma variação entre os falantes de português europeu, é possível encontrar uma escala de aceitabilidade que uniformiza alguns juízos (Gonçalves 1999; Fiéis/Madeira 2012). Assim, geralmente, como querer comportam-se conseguir, desejar, tentar, poder, dever, estar (a), ir, vir, entre outros, enquanto ousar, jurar, evitar se comportam como prometer. Já o verbo decidir é um dos que revela menor consenso entre os falantes, que ora o aproximam de querer ora o aproximam de prometer.

${ }^{9}$ Quando se associa ao verbo matriz, o clítico pode ocorrer em próclise (antes do verbo), em ênclise (depois do verbo) ou em mesóclise (no interior do verbo), de acordo com as regras gerais de colocação dos clíticos (cf. 15 A colocação dos pronomes clíticos em sincronia e diacronia). Vejam-se os exemplos (i), nos quais se ilustram as três posições, considerando o contexto de subida de clítico:
}

(i) a. Estás-me a ouvir? (ênclise)

b. Não me estás a ouvir? (próclise)

c. Estar-me-ás a ouvir? (mesóclise)

Ainda que os três padrões sejam admitidos em contexto de subida de clítico, a generalidade dos falantes considera que a próclise é o que produz melhores resultados. A ênclise é, muitas vezes, considerada estranha, sobretudo quando o clítico corresponde às formas acusativas $o, a, o s, a s$, caso em que a forma verbal e o clítico sofrem processos fonológicos que são responsáveis pela estranheza das frases. Veja-se o contraste entre (ia) e (ii):

(ii) ??/*Está-lo a ouvir?

Para evitar que fatores que não são de natureza sintática interfiram na gramaticalidade das frases, a generalidade dos exemplos do português europeu que apresentamos neste capítulo constituem casos de próclise. 
É de notar que o contraste entre (23c) e (24c) sugere que a hipótese de explicação do processo de formação de um predicado complexo de reestruturação não pode residir apenas na classe a que o verbo matriz pertence. Com efeito, os dois verbos matriz são verbos de controlo, mas apenas querer potencia a constituição de um predicado dessa natureza. Para além disso, o facto de o mesmo verbo apresentar um comportamento distinto em línguas diferentes constitui evidência empírica adicional a favor desta ideia: vejam-se, a este propósito, os exemplos do francês em (25), em que o verbo matriz, vouloir, não admite a formação de um predicado complexo (ver (25c)), ao contrário dos seus correspondentes em português e em italiano, respetivamente querer e volere:

(25) a. Je veux donner le livre à Jean.

b. Je veux lui donner le livre. [lui = à Jean]

c. *Je lui veux donner le livre.

A segunda propriedade estabelecida por Rizzi (1982) para identificar predicados complexos de reestruturação é, como já referimos, o movimento longo de objeto. Tal como em italiano, existe um contraste entre os verbos do português europeu que selecionam complementos infinitivos. Considerem-se os exemplos seguintes:

(26) Os inquilinos salvaram os móveis quando a casa já estava a arder.

(27) Quiseram-se salvar os móveis quando a casa já estava a arder.

(28) *Prometeram-se salvar os móveis quando a casa já estava a arder.

Em (26), uma frase ativa, o constituinte os móveis é selecionado pelo verbo salvar, tendo a função sintática de objeto direto. Na frase passiva pronominal em (27), este constituinte, sendo igualmente selecionado pelo verbo salvar, que ocorre no complemento infinitivo, é realizado como sujeito do verbo matriz. Assim, como acontece em italiano, também alguns verbos de controlo do português europeu admitem a construção de movimento longo de objeto, caracterizando-se, por isso, como verbos de reestruturação. Também como em italiano, verifica-se um contraste entre verbos de controlo, como se conclui do contraste entre (27) e (28). Note-se que os mesmos verbos que admitem subida de clítico admitem movimento longo de objeto e os que não admitem a primeira construção não admitem a segunda, o que revela, por parte destes verbos, um comportamento consistente quanto à possibilidade (ou impossibilidade) de formação de um predicado complexo. 
A terceira propriedade apontada por Rizzi (1982) para identificar um predicado complexo de reestruração diz respeito à mudança de auxiliar nos tempos compostos. Tal propriedade não se verifica em português europeu, uma vez que, nesta língua, o único auxiliar dos tempos compostos é ter.

Para além de verbos de controlo como querer, desejar, conseguir, tentar, entre outros, o grupo dos verbos de reestruturação integra, ainda, os semiauxiliares aspetuais (e.g. estar (a), começar (a), continuar (a)), modais (e.g., poder, dever) e temporais (e.g. ir), que podem ser incluídos na classe dos verbos de elevação (Gonçalves 1992, entre outros). Vejam-se os exemplos em (29) a (34), para cada uma destas classes de verbos e para cada propriedade de predicado complexo anteriormente identificada para $\mathrm{o}$ português europeu:

(i) Possibilidade de subida de clítico

(29) a. A Ana comprou uma nova gramática mas ainda não começou a consultá-la. b. A Ana comprou uma nova gramática mas ainda não a começou a consultar.

(30) a. Os alunos acabaram o trabalho e disseram que já podem entregá-lo.

b. Os alunos acabaram o trabalho e disseram que já o podem entregar.

(31) a. A Maria não contou a verdade aos pais porque eles não vão compreendê-la. b. A Maria não contou a verdade aos pais porque eles não a vão compreender.

(ii) Movimento longo de objeto

(32) Já se começaram a construir casas para os desalojados das cheias.

(33) Os resultados do concurso já se podem consultar no Diário da República.

(34) Todos os resultados do concurso se vão publicar no Diário da República.

Relativamente aos verbos causativos (mandar, deixar, fazer) e aos percetivos (ver, ouvir, sentir), o português europeu aproxima-se, de novo, do francês e do italiano, no sentido em que também esses verbos podem encabeçar um predicado complexo do tipo fazer-Inf quando selecionam complementos de infinitivo não flexionado. Vejam-se, a este propósito, os exemplos em (35) a (38):

(i) Subida de clítico com causativos (cf. (35)) e percetivos (cf. (36)) 
(35) a. O professor mandou consultar a pauta aos alunos.

b. O professor mandou-a consultar aos alunos. [ $a=a$ pauta $]$

c. O professor mandou-lhes consultar a pauta. [lhes = aos alunos]

(36) a. O João ouviu cantar a Aida a uma cantora lírica australiana.

b. O João ouviu-a cantar a uma cantora lírica australiana.

c. 'O João ouviu-lhe cantar a Aida. ${ }^{10}$

(ii) Movimento longo de objeto com causativos (cf. (37)) e percetivos (cf. (38)) $)^{11}$

(37) Mandaram-se construir novas casas para os desalojados das cheias.

(38) Ouviram-se saltar rolhas de garrafas de champanhe.

Ainda que todos os verbos que entram na formação de predicados complexos manifestem um comportamento idêntico relativamente à subida de clítico e ao movimento longo de objeto, como se conclui da observação dos exemplos que foram apresentados nesta secção, existem, em português europeu, diferenças entre reestruturação e fazer-Inf.

São várias as propriedades que distinguem os dois tipos de predicados complexos em português europeu (cf. Gonçalves 1999). ${ }^{12}$ Em primeiro lugar, como também assinalado em Raposo (1981), os predicados complexos do tipo fazer-Inf, que integram um verbo causativo ou um percetivo, implicam uma alteração à ordem dos constituintes do domínio infinitivo, associada a uma reatribuição de funções sintáticas. Com efeito, neste contexto, como já se descreveu anteriormente para o francês (cf. (6) e (7)), o constituinte que, do ponto de vista semântico, corresponde ao sujeito lógico do verbo encaixado, apresenta, do ponto de vista sintático, propriedades de objeto direto ou de objeto indireto, consoante a transitividade do verbo, e ocorre em posição pós-predicado complexo. Assim, quando o verbo encaixado é intransitivo, o constituinte em causa pode ser substituído pelo clítico acusativo $o$, que identifica o objeto direto (cf. (39)); pelo contrário, quando o verbo encaixado é transitivo, o referido constituinte, quando

\footnotetext{
${ }^{10}$ A presença do clítico dativo em predicados complexos com verbos percetivos não é igualmente admitida pelos falantes de português europeu. Ver também adiante, nota 18.

${ }^{11}$ Com base numa pesquisa no corpus CRPC, Vasconcelos (2013) mostra que o movimento longo de objeto é mais frequente em estruturas com causativos, percetivos e verbos de elevação como os semiauxiliares do que com os verbos de controlo (querer, conseguir, tentar, pretender, por exemplo).

${ }^{12}$ Embora estejam relatadas várias diferenças entre os dois tipos de predicados complexos, selecionámos apenas três, a título ilustrativo. Para mais informação sobre o português europeu, ver Gonçalves (1999).
} 
pronominalizado, assume a forma dativa do clítico, lhe, que identifica o objeto indireto (cf. (40)):

(39) a. O treinador mandou correr os atletas.

b. O treinador mandou-os correr.

(40) a. O Luís mandou arranjar o carro da mulher ao mecânico mais antigo da cidade.

b. O Luís mandou-1he arranjar o carro da mulher.

Dado que os constituintes assinalados em (39a) e (40a) não manifestam as propriedades típicas de um sujeito (nomeadamente, não são substituíveis pela forma nominativa do pronome pessoal, elelelaleles/elas), passaremos a designá-los como «causado»(do inglês, causee). Voltaremos a esta questão na secção 4.

Em segundo lugar, os dois tipos de predicados complexos distinguem-se quanto à passiva: o complemento infinitivo dos verbos de reestruturação pode ocorrer na forma passiva (cf. (41)), ao contrário do que acontece no contexto de fazer-Inf (cf. (42)):

(41) a. O Pedro já conseguiu [ser apresentado à Maria (pelo Mário)].

b. O Pedro já lhe conseguiu ser apresentado (pelo Mário).

(42) *O Pedro já mandou ser apresentado o Pedro à Maria (pelo Mário) nessa noite.

Finalmente, na construção fazer-Inf observa-se uma maior restrição quanto à natureza dos clíticos que sofrem o fenómeno que designámos como subida de clítico. Considerem-se os exemplos (43) e (44):

(43) a. Todos os adolescentes se querem barbear com a máquina do pai.

b. O Luís nunca se quis queixar das dores que tinha antes de ser operado.

(44) a. *O João mandou-se barbear (a)o Pedro $_{i}$.

b. *O João mandou-se $e_{i}$ queixar das dores (a)o Luís $\mathrm{i}_{\text {. }}$.

Enquanto em (43), um contexto de reestruturação, a ocorrência de clíticos reflexos (em (a)) e inerentes ${ }^{13}$ (em (b)) produz um resultado gramatical, em (44), exemplificativo de fazer-Inf, os mesmos clíticos não podem realizar-se em adjacência ao verbo causativo se tiverem como antecedente o causado. Esta diferença decorre de propriedades do complemento infinitivo, em particular no que diz respeito à natureza e à posição do

\footnotetext{
${ }^{13}$ Os clíticos inerentes são os que fazem parte integrante do próprio verbo, como em queixar-se, suicidarse, portar-se (bem/mal), entre outros.
} 
sujeito/causado neste complemento (Gonçalves 1999). Nas secções 3 e 4, caracterizaremos com mais pormenor os dois tipos de predicados complexos em português europeu.

\subsection{Aspetos de variação na formação de predicados complexos}

A possibilidade de formação de predicados complexos é um dos aspetos diferenciadores entre português europeu e português brasileiro. A ausência de predicados complexos tem sido normalmente apontada como fenómeno característico do português brasileiro (Cyrino 2008; 2010; entre outros), em evidência na agramaticalidade dos seguintes exemplos (Cyrino 2010, 200-201):

(45) a. *O João mandou comer a sopa à Ana. b. *O João mandou-lhe comer a sopa.

(46) a. *O João viu sair a Maria. b. *O João viu-a sair. (português brasileiro) (português brasileiro)

(português brasileiro) (português brasileiro)

Além da inexistência da construção fazer-Inf exemplificada em (45) e (46), em português brasileiro os clíticos são realizados no domínio do verbo encaixado, sem que ocorra subida do clítico, o que mostra também a ausência de predicados complexos de reestruturação nesta variedade:

(47) João pode/quer te ver. (português brasileiro; adaptado de Cyrino 2010, 200, ex. (23))

Esta diferença entre português europeu e português brasileiro decorre de diferenças na estrutura associada ao domínio do verbo infinitivo, que não permite a formação de um predicado complexo, pelo que o clítico ocorre obrigatoriamente nesse domínio.

Os contextos aqui considerados, que potenciam reestruturação em português europeu padrão, apresentam ocasionalmente manifestações não padrão de infinitivo flexionado (descritas para variedades de português europeu, assim como para variedades de português em África; cf. e.g. Gonçalves/Santos/Duarte 2014; A. Gonçalves 2014; P. Gonçalves 2015), excluindo-se nesse caso a possibilidade de formação de um predicado complexo:

(48) a. Vás seres apanhado...

b. Começas a teres o que queres...

(português europeu não padrão, in Carrilho/Lobo 1999) 
c. Se a gente andarmos a apanharmos cana...

(português europeu não padrão, in Carrilho/Lobo 1999)

(49) a. As pessoas preferem ganharem naquela hora mesmo.

b. As mulheres devem fabricarem panelas de barro e depois vão venderem.

(português de Moçambique, in Gonçalves 2015, 11 (exs. 1a-b))

Finalmente, notamos a existência de variação quanto aos verbos matriz que permitem subida do clítico (cf. também nota 8, acima). Em (50), por exemplo, ocorre subida de clítico no contexto de um verbo (permitir) que, para alguns falantes, exclui tal possibilidade.

(50) Sou professor provisório sem preparação específica para a docência nem estágio, porque o Estado nunca mo permitiu fazer.

(CETEMPúblico, Ext=753989)

Com base em dados do corpus dialetal CORDIAL-SIN, Magro (2005) encontra também contextos adicionais de subida de clítico, concluindo que variedades do português europeu diferentes da variedade padrão são normalmente mais permissivas em relação a este fenómeno. ${ }^{14}$

Uma vez que a subida de clítico constitui um dos critérios considerados na definição de predicados complexos, esta variação evidencia uma potencial margem de alargamento da identificação de predicados complexos em português europeu.

\section{A construção de reestruturação em português europeu}

Os dados apresentados na secção 2 mostram que existem verbos de controlo e de elevação do português europeu que, selecionado um complemento infinitivo, podem formar um predicado complexo de reestruturação com o verbo deste complemento. No entanto, como se mostrou em (23c) e (24c), repetidos em (51), apenas um subconjunto de verbos das mesmas classes pode, de facto, legitimar a formação do predicado complexo:

(51) a. O treinador não os quis contratar.

b. *O treinador não os prometeu contratar.

\footnotetext{
${ }^{14}$ Entre os verbos assinalados por Magro (2005), combinados com as preposições introdutoras da oração completiva infinitiva, encontram-se acabar (de), custar (a), usar (a), ir (para), ter (de).
} 
A primeira questão que se coloca é a de saber de que forma a subida de clítico e o movimento longo de objeto são indicadores de que os dois verbos formam um predicado complexo, isto é, de que os dois verbos constituem uma unidade sintática.

\subsection{Da monoracionalidade...}

Existem vários argumentos empíricos a favor da ideia, já herdada de Rizzi (1978; 1982), de que o verbo do complemento infinitivo e o próprio complemento perdem, em parte, a sua autonomia sintática, na construção de reestruturação. Esta observação tem levado diversos autores a propor que, nesta construção, existe um único domínio frásico (Rizzi 1978; 1982; Wurmbrand 2001; 2004; 2006; Cinque 2006). Assim, tal como descrito para o italiano por Rizzi, em português europeu são observáveis os seguintes factos:

(i) Quando ocorre um verbo que pode desencadear a reestruturação, a coocorrência de modificadores com valores temporais que não se intersetam, afetando cada um deles um domínio distinto, produz um resultado agramatical (cf. (52)). O mesmo não acontece se o verbo não desencadear reestruturação (cf. (53)).

(52) *Os jornalistas, ontem, quiseram entrevistar esse candidato amanhã.

(53) Os jornalistas, ontem, prometeram entrevistar esse candidato amanhã.

Note-se que o verbo querer, como prometer, seleciona um complemento infinitivo com uma leitura de posterioridade (isto é, a situação descrita nesse complemento é necessariamente posterior à situação descrita na oração matriz), pelo que (52) deveria ser gramatical. Voltaremos a esta questão mais adiante.

(ii) Se os dois verbos formarem um predicado complexo, sendo possível a subida de clítico, o advérbio de negação frásica não pode ocorrer no domínio encaixado, o que decorre do facto de os dois verbos formarem uma unidade, pelo que não é possível negar apenas a situação encaixada, como se conclui da agramaticalidade de (54b). Note-se que, se os dois verbos se mantiverem autónomos, não formando um predicado complexo, o complemento infinitivo pode ser negado de forma independente (cf. (54c)).

(54) a. Depois de terem faltado à aula, os alunos só queriam não enfrentar a professora.

b. *Depois de terem faltado à aula, os alunos só a queriam não enfrentar. $[a=$ a professora $]$

c. Depois de terem faltado à aula, os alunos só queriam não a enfrentar. 
(iii) Se a reestruturação se verificar, a completiva infinitiva não pode ser deslocada de forma independente, como se conclui do contraste entre (55a) e (55b):

(55) a. Enfrentá-la, os alunos não quiseram.

b. *Enfrentar, os alunos não a quiseram.

(iv) A ocorrência de uma frase parentética entre os dois verbos do predicado complexo de reestruturação dá origem a uma sequência agramatical (cf. (56a)), facto que não se verifica se os dois verbos mantiverem a sua autonomia sintática (cf. (56b)).

(56) a. *Depois de terem faltado à aula, os alunos queriam-na - mas sabiam que não deviam enfrentar.

b. Depois de terem faltado à aula, os alunos só queriam - mas sabiam que não deviam enfrentá-la.

Os exemplos (52) a (56) mostram que, efetivamente, no contexto de reestruturação, os dois verbos revelam um forte grau de sintatização, ou seja, formam uma unidade sintática, o que poderá ser um indicador de que tal construção tem uma estrutura monoracional. ${ }^{15}$

\section{2 ... à bioracionalidade}

A questão que nos ocupará na presente secção é a seguinte: o facto de os dois verbos formarem uma unidade sintática implica necessariamente a existência de um único domínio frásico? Dito de outra forma, nos casos em que se verifica reestruturação, existe apenas uma frase, como defendido, entre outros, por Rizzi (1978; 1982), Wurmbrand (2001; 2004; 2006) e Cinque (2006)? A resposta a esta questão é negativa, como proposto em Bok-Bennema/Kampers-Manhe (1994), Roberts (1997), Gonçalves (1999), Bok-Bennema (2006), entre outros.

\footnotetext{
${ }^{15}$ Note-se, porém, que esta unidade sintática não corresponde a uma unidade morfológica em português europeu, como em outras línguas românicas: como já referido, a adjacência entre os dois verbos pode ser interrompida:

(i) Depois de terem faltado à aula, os alunos não a queriam mesmo enfrentar.
} 


\subsubsection{Propriedades temporais dos domínios infinitivos na construção de reestruturação ${ }^{16}$}

A impossibilidade de coocorrência de modificadores temporais com valores opostos exemplificada em (57) parece ser um argumento forte a favor da monoracionalidade da construção de reestruturação. Assim, a agramaticalidade dessa sequência seria naturalmente esperada: se existisse apenas um domínio frásico, toda a situação descrita se localizaria num único intervalo de tempo (sobre semântica temporal do português, cf. 12 Semântica e pragmática). É isso que se verifica em frases simples, com ou sem o auxiliar de tempos compostos:

(57) a. *O presidente, ontem, promulgou o decreto-lei hoje.

b. *O presidente, ontem, já tinha promulgado o decreto-lei anteontem.

Gonçalves/Cunha/Silvano (2010) mostram, no entanto, que o complemento infinitivo dos verbos de reestruturação pode possuir traços de temporalidade, localizando a situação que descreve num intervalo de tempo distinto daquele em que se localiza a situação matriz (isto é, aquela que é descrita através do verbo de reestruturação e seus argumentos), o que constitui um argumento empírico forte a favor da bioracionalidade das estruturas em que ocorre a reestruturação. Considere-se a frase (58):

O presidente não quis promulgar o decreto-lei.

Nesta frase, em que ocorre um verbo de controlo (querer) que potencia a formação de um predicado complexo de reestruturação, o intervalo de tempo em que se localiza a situação descrita na encaixada (promulgar o decreto-lei) é posterior ao intervalo de tempo em que se localiza a oração matriz, ou seja, corresponde a um futuro não realizado (cf. Stowell 1982) no momento em que o presidente mostrou não querer promulgar o decreto-lei. Neste aspeto, a frase (58) não se distingue de (59), em que se

\footnotetext{
${ }^{16}$ As propriedades temporais dos domínios de infinitivo não flexionado que são descritas nesta secção caracterizam não só o português europeu como o português brasileiro. Porém, como referimos na secção 2.3, esta última variedade não dispõe de predicados complexos. Assim, considerar os mecanismos de dependência temporal é crucial para dar conta de diferenças entre verbos matriz em português europeu, distinguindo os que permitem reestruturação dos que não a permitem, mas tais mecanismos são irrelevantes em português brasileiro, variedade em que a reestruturação é bloqueada por razões de natureza sintática, mesmo em contextos em que se verifica dependência temporal.
} 
verifica também uma relação de posterioridade entre o domínio infinitivo e o domínio matriz:

O presidente não prometeu promulgar o decreto-lei.

Os dados em (58) e (59) mostram que verbos como querer e prometer influenciam de forma decisiva a localização temporal da eventualidade encaixada - esta é posterior à situação descrita pela matriz, o que explica a agramaticalidade de (60).

(60) a. *O presidente quis ter promulgado o decreto-lei.

b. *O presidente prometeu ter promulgado o decreto-lei.

Assim, estes dois verbos têm a mesma orientação temporal, entendida como uma propriedade inscrita na entrada lexical dos verbos que selecionam complementos oracionais e que determina a localização temporal da situação descrita na frase encaixada como anterior, posterior ou sobreposta à situação descrita na oração matriz (Duarte/Gonçalves/Santos 2012; Gonçalves/Santos/Duarte 2014).

No entanto, querer e prometer têm comportamentos distintos relativamente à reestruturação: apenas o primeiro admite a formação de um predicado complexo deste tipo, como se observa pelo contraste entre (61a) e (61b):

(61) a. O presidente não o quis promulgar. [o=o decreto-lei]

b. ${ }^{*} \mathrm{O}$ presidente não o prometeu promulgar.

Não sendo querer e prometer distintos relativamente à orientação temporal (posterioridade), as orações subordinadas a estes verbos manifestam comportamentos distintos no que diz respeito aos mecanismos de dependência temporal. Assim, quando o verbo matriz é querer, o intervalo de tempo a partir do qual a situação descrita pelo complemento infinitivo é perspetivada (ou seja, o seu ponto de perspetiva temporal; Kamp/Reyle 1993) é o da oração matriz; neste caso, as duas situações partilham o mesmo domínio temporal, entendido como o intervalo de tempo ocupado por uma situação ou conjunto de situações temporalmente relacionadas (Declerck 1991). Por essa razão, a sequência (52), repetida em (62), é agramatical, mesmo que o requisito de posterioridade se verifique: a situação encaixada só pode tomar como ponto de perspetiva temporal o tempo da matriz e não o da enunciação, o que exclui advérbios de 
tempo dêiticos, como amanhã. Neste caso, constitui-se um único domínio temporal, e a oração encaixada é, portanto, temporalmente dependente da matriz.

(62) *Os jornalistas, ontem, quiseram entrevistar esse candidato amanhã.

Note-se que outros advérbios temporais com valor de futuro podem ocorrer, desde que integrem a situação encaixada no domínio temporal criado pela situação matriz:

(63) O presidente quis promulgar o decreto-lei no dia seguinte.

Pelo contrário, no contexto do verbo prometer, o ponto de perspetiva temporal do complemento infinitivo é tanto o intervalo de tempo em que se localiza a situação matriz como o momento da enunciação; neste sentido, as duas situações não partilham necessariamente o mesmo domínio temporal, pelo que (53), repetida em (64), é uma frase gramatical. Neste caso, a oração encaixada é, portanto, temporalmente independente da matriz.

(64) Os jornalistas, ontem, prometeram entrevistar esse candidato amanhã.

Os conceitos de orientação temporal e de (in)dependência temporal são cruciais para a reestruturação. Deste modo,

(i) Verbos que não têm uma orientação temporal especificada, não fixando, por isso, a localização temporal da situação encaixada (cf. (65)) não admitem reestruturação (cf. $(66 b))$ :

(65) a. O arquiteto não disse transportar consigo a planta do edifício em recuperação. (sobreposição)

b. O arquiteto não disse ter transportado consigo a planta do edifício em recuperação. (anterioridade)

c. O arquiteto não disse ir transportar consigo a planta do edifício em recuperação. (posterioridade)

(66) a. $\mathrm{O}$ arquiteto não disse transportá-la consigo.

b. ${ }^{*} \mathrm{O}$ arquiteto não a disse transportar.

(ii) Verbos que têm uma orientação temporal especificada, determinando a localização temporal da situação encaixada, desencadeiam reestruturação desde que tal situação seja obrigatória e exclusivamente integrada no domínio temporal criado pela situação matriz, 
sendo o seu ponto de perspetiva temporal apenas o tempo da matriz. Geralmente, o domínio infinitivo estabelece com o tempo da matriz uma relação de posterioridade ou de sobreposição. ${ }^{17}$ Desta forma, admitem reestruturação verbos de controlo como querer, desejar, conseguir, bem como verbos de elevação como os semiauxiliares aspetuais (estar $a$, começar a, continuar a), modais (poder, dever) e temporais (ir), mas não verbos de controlo como prometer, decidir, jurar, lamentar, entre outros.

Considerar que, na construção de reestruturação, o complemento infinitivo tem traços de temporalidade, ainda que se verifique uma relação de dependência temporal relativamente ao tempo da matriz, implica defender a bioracionalidade dessa construção. Tal análise tem algumas vantagens relativamente às abordagens que propõem a monoracionalidade da estrutura. Em primeiro lugar, explica por que razão se observam as mesmas relações temporais entre a oração encaixada e a matriz, exista ou não reestruturação; veja-se o contraste entre (67), sem reestruturação, e (68), com reestruturação:

(67) a. *O presidente não quis promulgá-lo amanhã.

b. O presidente não quis promulgá-lo no dia seguinte.

(68) a. *O presidente não o quis promulgar amanhã.

b. O presidente não o quis promulgar no dia seguinte.

Em segundo lugar, dá conta da diferença entre verbos de reestruturação e verbos auxiliares, como mostraremos na secção seguinte.

\subsubsection{Verbos de reestruturação e verbos auxiliares}

Como referido na Introdução, alguns verbos que admitem reestruturação foram classificados como auxiliares em diversas gramáticas do português, a par do verbo ter,

\footnotetext{
${ }^{17}$ Note-se que, em alguns casos, a subordinada parece ter uma interpretação de anterioridade mesmo que o verbo matriz tenha uma orientação temporal especificada para posterioridade:

(i) O João queria ter ido ao cinema.

No entanto, as frases deste tipo só são gramaticais quando o verbo matriz ocorre no pretérito imperfeito, que assume, aqui, um valor modal (de contrafactualidade, neste caso). Assim, frases como (i) podem ser seguidas de ...mas não [verbo encaixado]. Se esse valor não estiver presente, o resultado é agramatical. Compare-se (ii) com (iii):
}

(ii) O João queria ter ido ao cinema (mas não foi).

(iii) *O João quis ter ido ao cinema (mas não foi). 
auxiliar dos tempos compostos, e de ser, auxiliar da passiva (veja-se, em particular, Soares Barbosa 1822; Said Ali 1908; 1931; Epiphanio Silva Dias 1917; Bechara ${ }^{1} 1963$, ${ }^{37}$ 1999; Cunha/Cintra 1984). Um dos argumentos para tal classificação consiste na possibilidade de subida de clítico, propriedade que identifica predicados complexos. Com efeito, no contexto dos verbos auxiliares acima referidos, os clíticos dependentes do verbo principal, que ocorre no particípio passado, associam-se ao verbo auxiliar, o que, em parte, pode ser considerado como subida de clítico:

(69) a. A mãe do Zé só o tem visto aos fins de semana.

b. Não me foram apresentadas provas concretas de falsificação de documentos.

Note-se, porém, que, contrariamente ao que acontece na construção de reestruturação, o clítico não pode associar-se aos verbos principais em (70):

(70) a. *A mãe do Zé só tem visto-o aos fins-de-semana.

b. *Foram apresentadas-me provas concretas de falsificação de documentos.

Um outro aspeto que pode aproximar os verbos de reestruturação dos auxiliares é a impossibilidade de negação do domínio do segundo verbo:

(71) *A Teresa está tão aborrecida com o Miguel que só o quer não ver.

(72) a. *A Teresa tem não saído com o Zé.

b. *A documentação foi não entregue dentro do prazo legal de candidaturas.

No entanto, também neste aspeto há que distinguir entre verbos auxiliares e verbos de reestruturação. Com efeito, estes últimos podem ocorrer em contextos em que não se verifica reestruturação e, neste caso, a negação do domínio infinitivo produz um resultado gramatical (cf. (73)); pelo contrário, com os verbos auxiliares apenas é possível um operador de negação frásica, que precede obrigatoriamente o complexo <verbo auxiliar - verbo principal> (veja-se o contraste entre (72) e (74)).

(73) A Teresa está tão aborrecida com o Miguel que só quer não o ver.

(74) a. A Teresa não tem saído com o Zé.

b. A documentação não foi entregue dentro do prazo legal de candidaturas. 
As diferenças acima ilustradas constituem, assim, um argumento a favor da distinção entre verbos de reestruturação e verbos auxiliares. Em particular, mostram que os primeiros ocorrem em domínios bioracionais e os segundos, em domínios monoracionais. O facto de, quando se verifica reestruturação, existirem algumas propriedades que parecem apontar para a monoracionalidade da estrutura decorre da possibilidade de estes verbos selecionarem complementos defetivos, sintática e semanticamente, como defendido em Gonçalves (1999) e Gonçalves/Cunha/Silvano (2010), entre outros.

\subsection{Síntese}

No Quadro 1, sintetizam-se as propriedades apresentadas nas secções anteriores que caracterizam os predicados complexos de reestruturação em português europeu:

\begin{tabular}{|c|c|c|}
\hline \multirow{2}{*}{$\begin{array}{l}\text { Evidência de } \\
\text { formação de } \\
\text { predicado } \\
\text { complexo }\end{array}$} & $\begin{array}{l}\text { Possibilidade de } \\
\text { subida de clítico }\end{array}$ & Os rapazes não a quiseram conhecer. \\
\hline & $\begin{array}{l}\text { Movimento } \\
\text { longo do objeto }\end{array}$ & Quiseram-se salvar os móveis. \\
\hline \multirow{2}{*}{$\begin{array}{l}\text { Evidência / } \\
\text { características } \\
\text { de construção } \\
\text { de } \\
\text { reestruturação }\end{array}$} & $\begin{array}{l}\text { Reduzida } \\
\text { autonomia } \\
\text { sintática do } \\
\text { complemento } \\
\text { infinitivo / forte } \\
\text { grau de } \\
\text { sintatização }\end{array}$ & $\begin{array}{l}\text { - restrições sobre negação (em contexto de subida de } \\
\text { clítico): } \\
\quad \text { *Eles só a queriam não enfrentar. } \\
\text { - restrições sobre deslocação: } \\
\quad \text { *Enfrentar, os alunos não a quiseram. } \\
\text { - impossibilidade de parentética entre os dois verbos: } \\
\quad \text { *Eles queriam-na - mas sabiam que não deviam- } \\
\quad \text { enfrentar. }\end{array}$ \\
\hline & Bioracionalidade & $\begin{array}{l}\text { - apesar de restrições sobre as dependências temporais } \\
\text { entre a oração matriz e a oração encaixada, manutenção } \\
\text { de temporalidade no complemento infinitivo: } \\
\quad \text { O presidente não o quis promulgar no dia seguinte. }\end{array}$ \\
\hline \multicolumn{2}{|c|}{ Verbos matriz } & $\begin{array}{l}\text { Subconjunto de verbos de controlo: querer, desejar, } \\
\text { conseguir, tentar. } \\
\text { Subconjunto de verbos de elevação: semiauxiliares } \\
\text { modais }(\text { poder, dever), aspetuais }(\text { estar }(a) \text {, continuar }(a) \text {, } \\
\text { começar }(a)) \text {, temporais }(\text { ir }) \text {. }\end{array}$ \\
\hline
\end{tabular}

Quadro 1: Síntese das propriedades da construção de reestruturação em português europeu. 


\section{A construção fazer -Inf em português europeu}

O segundo tipo de construção de predicado complexo que aqui consideramos ocorre, como vimos, em contextos de complementação infinitiva de verbos causativos (como mandar, deixar, fazer) e percetivos (como ver, ouvir, sentir). Admitindo estes verbos, alternativamente, complementos oracionais de outro formato (cf. adiante, secção 4.2), interessa-nos, num primeiro momento, considerar exclusivamente os contextos que, com estes verbos, dão lugar à formação de um predicado complexo em português europeu, para caracterizarmos mais finamente as suas propriedades distintivas em relação à reestruturação. Restringimos pois o âmbito da primeira secção aos contextos em que o verbo encaixado é um infinitivo não flexionado e que permitem subida de clítico e movimento longo de objeto (cf., acima, 2.1 e 2.2). Em seguida, na secção 4.2, são apresentados alguns aspetos de comparação entre os diferentes tipos de complementos dos verbos causativos e percetivos, integrando dados de variação intra e interlinguística.

\subsection{Propriedades distintivas dos predicados complexos de tipo fazer-Inf}

Das diferenças entre os dois tipos de predicados complexos, destacámos, na secção 2.2, as seguintes características identificadoras de fazer-Inf: além do requisito de subida do clítico, comum à reestruturação, também restrições sobre a natureza dos clíticos que ocorrem em fazer-Inf; a impossibilidade de o infinitivo ser passivizado; e a alteração à ordem de constituintes do domínio infinitivo, associada a uma reatribuição de funções sintáticas. Estas propriedades correlacionam-se com uma menor autonomia do complemento infinitivo nestas construções, que resulta numa «amálgama de duas orações numa só» (Barbosa/Raposo 2013, 1963) - caracterização na base da designação «união de orações» também atribuída a este tipo de predicado complexo (Raposo 1981). Neste caso, os dois verbos formam um núcleo verbal complexo, com consequências na ordenação e nas funções sintáticas dos constituintes da frase, assim como na limitação de outras manifestações sintáticas, sintetizadas de seguida.

A família das línguas românicas manifesta assimetrias relativamente à ocorrência de pronomes reflexos de interpretação dependente do causado no domínio infinitivo. Assim, na construção fazer-Inf o clítico ocorre obrigatoriamente no domínio infinitivo em francês, mas não em italiano nem em português europeu (os exemplos do francês e do italiano são retirados de Guasti 1993): 
(75) a. Il faisait se réveiller la fille.

b. *Lui faceva svegliarsi la ragazza.

c. *O João mandou barbear-se o Pedro.

No contexto de subida de clítico caracterizador de fazer-Inf, verifica-se a mesma restrição sobre pronomes reflexos (e inerentes, como vimos na secção 2.2) em português europeu.

(76) *O João mandou-se i barbear o Pedro $_{\mathrm{i}}$.

A construção fazer-Inf distingue-se da reestruturação também pelo facto de o verbo infinitivo não poder ocorrer na forma passiva (cf. contraste em (41)-(42), aqui repetido como (77)-(78)):

(77) a. O Pedro já conseguiu [ser apresentado à Maria (pelo Mário)].

b. O Pedro já lhe conseguiu ser apresentado (pelo Mário).

(78) a. *O Pedro já mandou [ser apresentado o João à Maria (pelo Mário)].

b. *O Pedro já lhe mandou ser apresentado o João.

A passivização do verbo superior, envolvendo ou não se passivo (e movimento longo de objeto), pode no entanto ocorrer, realizando-se como sujeito o argumento interno do verbo infinitivo.

(79) a. Estas casas foram mandadas construir a arquitetos famosos.

b. Mandaram-se construir algumas casas a arquitetos famosos.

A propriedade mais específica dos predicados complexos fazer-Inf diz respeito à reorganização de funções sintáticas no complemento infinitivo, que afeta, particularmente, o constituinte classicamente designado como sujeito, a que temos vindo a chamar causado. Este constituinte, ao contrário dos sujeitos típicos, realiza-se como um sintagma preposicional em contextos de verbo transitivo (cf. (81)) e pode ser substituído por um clítico acusativo (em (80)) ou por um clítico dativo (em (81)), que correspondem, respetivamente, ao objeto direto e ao objeto indireto:

(80) a. $\mathrm{O}$ treinador mandou correr os atletas. $\rightarrow \mathrm{O}$ treinador mandou-os correr.

b. Os pais do Luís ouviram cantar a Maria Callas. $\rightarrow$ Os pais do Luís ouviram-na cantar.

(81) a. O Luís mandou arranjar o carro da mulher ao mecânico mais antigo da cidade.

$\rightarrow$ O Luís mandou-lhe arranjar o carro da mulher. 
b. ?'Os pais do Luís ouviram cantar La Traviata à Maria Callas. ${ }^{18}$

$\rightarrow$ ?'Os pais do Luís ouviram-lhe cantar La Traviata.

Relativamente a esta questão, encontram-se na literatura dois tipos de abordagens: aquelas em que o causado é caracterizado como o sujeito do verbo no infinitivo (cf. Kayne 1975; Burzio 1986; Villalba 1992; Guasti 1993; 1997; Folli/Harley 2007; entre outros) e aquelas em que o mesmo é reanalisado em termos da sua função sintática (cf. Raposo 1981; Alsina 1996; Gonçalves 1999; entre outros).

A ideia de que o causado, na construção fazer-Inf, corresponde ao sujeito, embora, por razões que não se exploram no presente capítulo, apresente propriedades que não são típicas desta função sintática, encontra fundamento em diferentes factos. Em primeiro lugar, é semanticamente dependente do verbo encaixado, o que explica a agramaticalidade de (82b):

(82) a. O professor fez ler o livro ao Pedro.

b. *O professor fez ler o livro aos cães.

Note-se que, no contexto do mesmo verbo causativo, fazer, é possível a ocorrência do constituinte que gera a agramaticalidade em (82b), aos cães, se se alterar o verbo encaixado:

O professor fez comer a ração aos cães.

Adicionalmente, em algumas línguas, como o italiano, o causado pode qualificar-se como antecedente de expressões anafóricas que ocorrem na posição de objeto direto, como os pronomes reflexos (cf. (84a)), ou fixar a referência do sujeito nulo de frases encaixadas selecionadas pelo verbo do complemento infinitivo (cf. (84b)), propriedades que partilha com o sujeito típico:

(84) a. Con le minacce, fecero accusare se stesso ${ }_{i}$ a Giovanni $i_{i}$.

b. Ho fatto affermare di $[-]_{i}$ averla visto a Giovanni ${ }_{i}$.

(Burzio 1986)

(Burzio 1986)

Os exemplos do português europeu correspondentes a (84) são, porém, agramaticais:

(85) a. *O João \{mandou lavar-se ${ }_{i} /$ mandou-se $_{i}$ lavar $\}$ (a)os meninos . $_{\text {. }}$

b. *O Miguel mandou dizer [-i ter visto a Ana ao Zéi $]$.

\footnotetext{
${ }^{18}$ Os falantes de português europeu manifestam alguma divergência em relação à gramaticalidade deste tipo de sequência. Como complemento de verbos percetivos, o infinitivo não flexionado com alteração de funções sintáticas é por vezes sentido como marginal para alguns falantes quando o verbo infinitivo é transitivo (cf. também Barbosa/Raposo 2013, 1962, n.79).
} 
Adicionalmente, em português o causado apresenta outras propriedades que o distinguem do sujeito típico do verbo infinitivo, aproximando-o de um objeto (objeto direto ou objeto indireto):

i. $\quad$ se o verbo encaixado for transitivo, o causado não pode estar associado a quantificadores flutuantes (como todos em (86)):

(86) *Aos meninos, o professor mandou ler todos um livro.

Note-se que em contextos não causativos, os sujeitos podem estar associados a quantificadores flutuantes (cf. (87)), mas os objetos indiretos, não (cf. (88)):

(87) Os meninos leram todos um livro.

(88) * Aos meninos, a Marta deu todos as bolachas.

ii. quando o objeto direto integra um quantificador distributivo, pode ser antecedente local de expressões de posse que ocorram no causado:

(89) O Presidente mandou defender [cada proposta $]_{\mathrm{i}}$ ao $\mathrm{seu}_{\mathrm{i}}$ autor.

Note-se que em contextos não causativos, o objeto direto não pode ser antecedente local de expressões de posse que ocorram no sujeito (cf. (90)), mas pode ser antecedente de expressões que ocorram no objeto indireto (cf. (91)):

(90) $* \mathrm{O} \mathrm{seu}_{\mathrm{i}}$ autor defendeu [cada proposta $]_{\mathrm{i}}$

(91) O professor deu [cada livro] $]_{i}$ ao $\operatorname{seu}_{\mathrm{i}}$ autor.

\subsection{Fazer-Inf e outros complementos de verbos causativos e percetivos em português europeu}

Em português europeu os verbos causativos e percetivos apresentam um leque variado de complementos oracionais que constituem alternativas à formação de um predicado complexo de tipo fazer-Inf (cf. (92)): complementos finitos (ex. (93)), de infinitivo flexionado (ex. (94)), de infinitivo não flexionado com ordem sujeito-verbo (ex. (95)) - 
cf. e.g. Silva 1999; Gonçalves/Duarte 2001; Duarte/Gonçalves 2002; Martins 2004;

Barbosa/Raposo 2013. ${ }^{19}$

(92) a. A presidente da Assembleia mandou votar a lei aos deputados.

b. 'A presidente da Assembleia viu votar a lei aos deputados. ${ }^{20}$

(93) a. A presidente da Assembleia mandou que os deputados votassem a lei.

b. A presidente da Assembleia viu que os deputados votaram a lei.

(94) a. A presidente da Assembleia mandou os deputados votarem a lei.

b. A presidente da Assembleia viu os deputados votarem a lei.

(95) a. A presidente da Assembleia mandou todos os deputados votar a lei.

b. A presidente da Assembleia viu os deputados votar a lei.

Os verbos percetivos podem ainda selecionar um complemento infinitivo (flexionado ou não) introduzido pela preposição $a$, com a mesma distribuição do gerúndio, nos dialetos em que este ocorre (cf. $18 \mathrm{O}$ gerúndio flexionado no português dialetal). ${ }^{21}$ Neste caso, o complemento infinitivo assume o valor aspetual de progressivo.

(96) a. A presidente da Assembleia viu todos os deputados a votar(em) a lei.

b. A presidente da Assembleia viu todos os deputados votando a lei.

De todos estes contextos, apenas (92) integra um predicado complexo do tipo fazer-Inf. Com efeito, considerando que a subida de clítico é um indicador da existência deste tipo de predicados, verifica-se que o clítico correspondente ao constituinte a lei (objeto direto do verbo votar) só pode associar-se ao verbo causativo ou ao verbo percetivo em (92), dando origem a (97), que contrasta com (98)-(100).

(97) a. A presidente da Assembleia mandou-a votar aos deputados b. 'A presidente da Assembleia viu-a votar aos deputados. ${ }^{22}$

(98) a. *A presidente da Assembleia mandou-a que os deputados votassem. b. *A presidente da Assembleia viu-a que os deputados votaram.

\footnotetext{
${ }^{19}$ Para outras variantes não-padrão, ver Pereira $(2012 ; 2015)$.

${ }^{20} \mathrm{Cf}$. nota 18 .

${ }^{21}$ Raposo (1989) designa esta construção como «Construção de Infinitivo Preposicionado» (Prepositional Infinitive Construction). Relativamente ao elemento que introduz o complemento infinitivo, $a$, existem divergências quanto à sua classificação: preposição (Raposo 1989) ou marcador aspetual (Duarte 1993; Gonçalves/Duarte 2001; Barbosa/Cochofel 2005).

${ }^{22}$ Cf. nota 18.
} 
(99) a. *A presidente da Assembleia mandou-a os deputados votarem.

b. *A presidente da Assembleia viu-a os deputados votarem.

(100) a. *A presidente da Assembleia mandou-a os deputados votar.

b. *A presidente da Assembleia viu-a os deputados votar.

(101) *A presidente da Assembleia viu-a os deputados a votar(em).

Como se mostrou na secção 2.2, a existência de predicados complexos de tipo fazer-Inf não é um traço específico do português europeu. Pelo contrário, trata-se de uma construção que caracteriza transversalmente as línguas românicas, em particular na expressão de uma causativa (também referida «causativa românica», cf. Guasti 1997).

A este respeito, no seio das línguas românicas, a especificidade do português advém da diversidade de estruturas que apresenta. Em particular, o português europeu permite, a par de fazer-Inf, o tipo de complementos infinitivos flexionados exemplificados em (94), uma possibilidade que não se encontra igualmente disponível noutras línguas, nem mesmo em galego, que apresenta infinitivos flexionados noutros contextos (cf. Álvarez/Xove 2002, 308; Carrilho/Sousa 2010):

(102) a. Ana fixo saír os alumnos. / Ana fixo os alumnos saír.

b. *Ana fixo os alumnos saíren. (galego; in Carrilho/Sousa 2010, 4, ex. (7))

Além disso, o português (neste caso, a par do galego) dispõe também da construção com infinitivo não flexionado e com ordem sujeito-verbo no domínio deste infinitivo (cf. (95); em (102) exemplifica-se a mesma possibilidade em galego). Pelo contrário, em italiano, espanhol e francês, esta ordem é possível com os correspondentes do verbo causativo deixar e dos verbos percetivos (cf. (103) e (104)), mas não com os restantes causativos (cf. (105)). ${ }^{23}$

(103) a. Gianni ha lasciato Maria mangiare la mela.

b. Deja el agua correr.

c. Je laisserai Marie parler.

(104) a. Gianni ha visto Carlo mangiare la mela.

b. Veo (a) la televisión funcionar.

c. J'ai vu Marie parler.

(105) a. *Gianni ha fatto Maria parlare.

${ }^{23}$ Sobre a proximidade estrutural entre os complementos infinitivos de causativas e percetivas em português e em inglês (John saw/heard/made her hit Fred.), veja-se Hornstein/Martins/Nunes (2008). 
b. *Juan hizo la televisión funcionar. ${ }^{24}$

c. *Jean a fait son amie partir.

Estes complementos infinitivos não flexionados em português apresentam ambiguidade com instâncias da construção fazer-Inf quando o causado é pronominalizado, uma vez que este é casualmente marcado como acusativo, numa estrutura designada de «Marcação Excecional de Caso» (pelo verbo matriz). No caso de fazer-Inf, o causado/sujeito também pronominaliza em forma de acusativo quando o verbo infinitivo é intransitivo, o que potencia a ambiguidade:

(106) a. A presidente da Assembleia mandou-os entrar. [=A presidente da Assembleia mandou os deputados entrar] [=A presidente da Assembleia mandou entrar os deputados] (fazer-Inf)

b. A presidente da Assembleia viu-os entrar. [=A presidente da Assembleia viu os deputados entrar] [=A presidente da Assembleia viu entrar os deputados] (fazer-Inf)

Distinguem-se, no entanto, nas formas pronominais de terceira pessoa semanticamente dependentes de verbos infinitivos transitivos (neste contexto, um causado/sujeito realiza-se pronominalmente como dativo na construção de fazer-Inf (107b/d) e como acusativo na construção de infinitivo não flexionado (107a/c)):

(107) a. A presidente da Assembleia mandou-os votar a lei. [=A presidente da Assembleia mandou os deputados votar a lei]

b. A presidente da Assembleia mandou-lhes votar a lei. [=A presidente da Assembleia mandou votar a lei aos deputados] (fazer-Inf)

c. A presidente da Assembleia viu-os votar a lei. [=A presidente da Assembleia viu os deputados votar a lei]

d. 'A presidente da Assembleia viu-lhes votar a lei. [=A presidente da Assembleia viu votar a lei aos deputados]

As duas construções apresentam diferenças relacionadas com a diversidade estrutural de fazer-Inf e de construções de infinitivo não flexionado, evidenciadas, a título de

\footnotetext{
${ }^{24}$ Em espanhol, em alguns contextos, o causado pode ocorrer em posição pré-verbal, sendo introduzido pela preposição $a$ :

(i) Juan hizo a la radio funcionar. (Torrego 1998)

(ii) La entrenadora hizo a la atleta repetir el ejercicio. (Torrego 2010)

Há, no entanto, algumas restrições fortes sobre esta possibilidade; ver Torrego (1998; 2010) e Hernanz (1999).
} 
exemplo, em (108), pelo comportamento divergente que as construções causativas exibem em relação à presença da negação no domínio infinitivo: ${ }^{25}$

(108) a. *A presidente da Assembleia mandou não votar a lei aos deputados. / *A presidente da Assembleia mandou-lhes não votar a lei.

(fazer-Inf)

b. A presidente da Assembleia mandou os deputados não votar a lei. / A presidente da Assembleia mandou-os não votar a lei.

Para concluir, consideram-se alguns dados empíricos da distribuição destas diferentes construções em português europeu. Contrastando com outras línguas românicas, destaca-se normalmente a prevalência, em português europeu, de construções diferentes de fazer-Inf, em especial a construção de «Marcação Excecional de Caso», ou seja, aquela em que o infinitivo não flexionado ocorre com um causado preverbal cliticizável generalizadamente em acusativo (cf. e.g. Silva 1999, Gonçalves/Duarte 2001, Sousa 2004). Investigação recente (Pereira 2012), sobre dados de variedades regionais (e sociais) diferentes da variedade padrão do português europeu, reunidos no corpus dialetal CORDIAL-SIN, revelam no entanto que esta prevalência não deve ser homogeneamente entendida. Por um lado, Pereira (2012) encontra predomínio de fazerInf como complemento de verbos causativos. Em contextos de verbos perceptivos, apenas a construção de infinitivo preposicionado a ultrapassa. Por outro lado, a distribuição geográfica das variantes encontradas (cf. contraste entre Mapas 1 e 2) permite evidenciar uma área meridional e açoriana - uma área que contém o centro geográfico difusor da variedade padrão -, na qual se concentram as construções que diferem de fazer-Inf.

\footnotetext{
${ }^{25}$ No caso dos verbos percetivos a presença de negação produz efeitos agramaticais mesmo em contexto em que não se forma um predicado complexo, por razões decorrentes das propriedades semânticas destes verbos.
} 


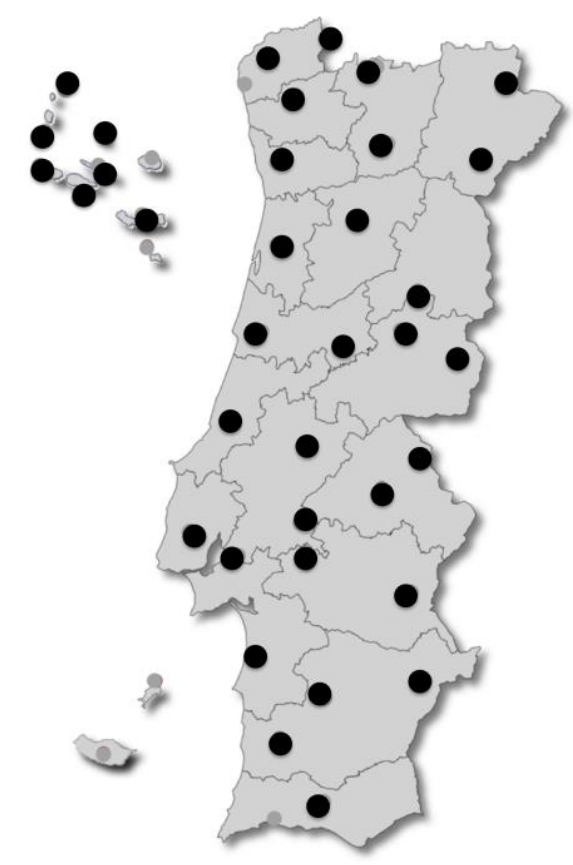

Mapa 1: Distribuição geográfica de fazer-Inf com verbos causativos no CORDIAL-SIN (Pereira 2012)

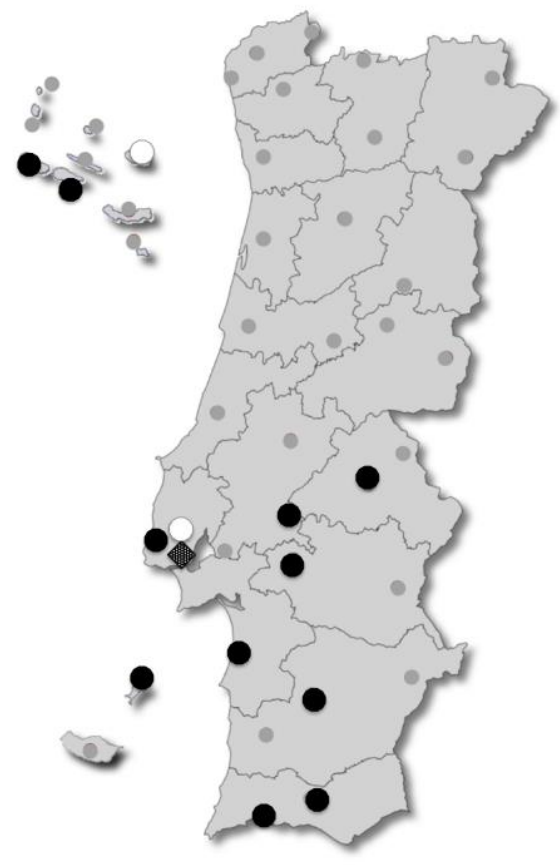

Mapa 2: Distribuição geográfica de construções diferentes de fazer-Inf com verbos causativos no CORDIAL-SIN (Pereira 2012)

\section{Conclusões gerais}

Identificadas as principais características sintático-semânticas da formação de predicados complexos verbais em português europeu, destaca-se que:

(i) o português europeu apresenta os dois tipos de predicados complexos sintáticos identificados nas línguas naturais, predicados complexos de reestruturação e de tipo fazer-Inf;

(ii) como descrito na literatura especializada, estas duas construções apresentam diferenças sintáticas também em português europeu, sendo a mais relevante a menor autonomia sintática dos domínios infinitivos que ocorrem em predicados complexos de tipo fazer-Inf;

(iii) o português europeu regista, a este respeito, importantes diferenças em relação ao português brasileiro, que não apresenta predicados complexos;

(iv) no seio das línguas românicas, o português europeu se distingue por ter disponíveis os dois tipos de predicados complexos e pela diversidade de verbos que, de modo mais generalizado, entram em cada uma das construções;

(v) no seio das línguas românicas, o português europeu se distingue pela diversidade de construções que concorrem com um predicado complexo (fazer-Inf) em construções com verbos causativos e percetivos; 
(vi) no domínio da variação interna ao português europeu, existe uma maior diversidade de verbos que admitem reestruturação;

(vii)considerada a distribuição geográfica de construções alternativas a um predicado complexo fazer-Inf, existe uma oposição entre o predicado complexo, mais generalizadamente distribuído por todo o território, e outras construções, que se encontram geograficamente concentradas numa área de predomínio meridional.

\section{Referências}

Alsina, Alex (1996), The Role of Argument Structure in Grammar. Evidence from Romance, CSLI Lecture Notes 62, Stanford, CSLI Publications.

Alsina, Alex (1997), Causatives in bantu and Romance, in: Alex Alsina/Joan Bresnan/Peter Sells (edd.), Complex predicates, CSLI Lecture Notes 64, Stanford, CSLI Publications, 203-246.

Álvarez, Rosario/Xove, Xosé (2002), Gramática da Língua Galega, Galáxia, Vigo.

Baker, Mark (1988), Incorporation, Chicago, University of Chicago Press.

Baker, Mark (1996), The Polisynthesis Parameter, Oxford, Oxford University Press.

Barbosa, Pilar/Cochofel, Fátima (2005), O Infinitivo Preposicionado em PE, in: Inês Duarte/Isabel Leiria (edd.), Actas do XX Encontro Nacional da Associação Portuguesa de Linguística, Lisboa, APL, 387-400.

Barbosa, Pilar/Raposo, Eduardo B. Paiva (2013), Subordinação verbal infinitiva, in: Eduardo B. Paiva Raposo et al. (orgs.), Gramática do Português, vol. II, cap. 37, Lisboa, Fundação Calouste Gulbenkian, 1899-1977.

Bech, Gunnar ( $\left.{ }^{1} 1955-1957,{ }^{2} 1983\right)$, Studien über das deutsche Verbum infinitivum, Tübingen, Niemeyer.

Bechara, Evanildo $\left({ }^{1} 1963,{ }^{37} 1999\right)$, Nova Gramática Portuguesa, São Paulo, Companhia Editora Nacional.

Bok-Bennema, Reineke (2006), Clitic Climbing, in: Henk van Riemsdijk et al. (edd.), The Blackwell Companion to Syntax, Volume I-V, Blackwell Handbooks in Linguistics, Malden, Massachusetts, Blackwell Publishing, 469-518.

Bok-Bennema, Reineke/Kampers-Manhe, Brigitte (1994), Transparency effects in the Romance languages, in: Michael L. Mazzola (ed.), Issues and theory in Romance linguistics, Washington, D.C., Georgetown University Press, 199-217.

Bordelois, Ivonne (1988), Causatives: from Lexicon to Syntax, Natural Language and Linguistic Theory 6, 57-93.

Burzio, Luigi (1986), Italian Syntax: a Government-Binding approach, Dordrecht, Kluwer.

Carrilho, Ernestina/Lobo, Maria (1999) Variação sintáctica: alguns aspectos, comunicação apresentada no ciclo de conferências Conversas d'HorAl organizado pelo CLUL, 15 Junho 1999.

Carrilho, Ernestina/Sousa, Xulio (2010), Embedded subjects of causative infinitival constructions in Galician and Portuguese, 6th International Constrastive Linguistics Conference, Freie University Berlin, October 2010, ms., http://www.clul.ul.pt/files/ernestina_carrilho/CarrilhoSousa2010tx.pdf (21.04.2016).

CETEMPúblico - Corpus de Extratos de Textos Eletrónicos MCT/Público, http://www.linguateca.pt/CETEMPublico/ (21.04.2016).

Chomsky, Noam (1981), Lectures on Government and Binding, Dordrecht, Foris.

Cinque, Guglielmo (2006), Restructuring and Functional Heads. The Cartography of Syntactic Structures, vol. 4, New York, Oxford University Press.

CORDIAL-SIN - Syntax-oriented Corpus of Portuguese Dialects, Lisboa, CLUL, http://www.clul.ul.pt (13.05.2016). 
CRPC - Corpus de Referência do Português Contemporâneo, Lisboa, CLUL, http://alfclul.clul.ul.pt/CQPweb (21.04.2016).

Cunha, Celso/Cintra, Luis Filipe Lindley (1984), Nova Gramática do Português Contemporâneo, Lisboa, Sá da Costa.

Cyrino, Sonia (2008), On the lack of complex predicates in Brazilian Portuguese, comunicação apresentada no 18th Colloquium on Generative Grammar, Universidade de Lisboa.

Cyrino, Sonia (2010), On Romance syntactic complex predicates: why Brazilian Portuguese is different, Estudos da Língua(gem) 8:1, 187-222.

Declerck, Renaat (1991), Tense in English: Its Structure and Use in Discourse, Londres/Nova Iorque, Routledge.

Duarte, Inês (1993), Complementos infinitivos preposicionados e outras construções temporalmente defectivas em Português Europeu, in: Actas do VIII Encontro da Associação Portuguesa de Linguística, Lisboa, APL, 145-158.

Duarte, Inês (2003), Subordinação completiva - as orações completivas, in: Maria Helena Mira Mateus et al. (edd.), Gramática da Língua Portuguesa, Lisboa, Caminho, 593-651.

Duarte, Inês (2013), Construções ativas, passivas, incoativas e médias, in: Eduardo B. Paiva Raposo et al. (orgs.), Gramática do Português, vol. I, cap. 13, Lisboa, Fundação Calouste Gulbenkian, 428-458.

Duarte, Inês/Gonçalves, Anabela (2002), Construções de subordinação funcionalmente defectivas: o caso das construções perceptivas em português europeu e em português brasileiro, in: Anabela Gonçalves/Clara Nunes Correia (edd.), Actas do XVII Encontro da Associação Portuguesa de Linguística, Lisboa, APL, 161-173.

Duarte, Inês/Gonçalves, Anabela/Santos, Ana Lúcia (2012), Infinitivo flexionado, independência temporal e controlo, in: Armanda Costa/Cristina Flores/Nélia Alexandre (edd.), Textos Selecionados, XXVII Encontro Nacional da Associação Portuguesa de Linguística, Lisboa, APL, 217-234.

Epiphanio da Silva Dias, Augusto (1917), Syntaxe Histórica Portuguesa, Lisboa, Livraria Clássica Editora.

Fiéis, Alexandra/Madeira, Ana Maria (2012), Predicados de controlo na diacronia do Português, in: Armanda Costa/Cristina Flores/Nélia Alexandre (edd.), Textos Selecionados, XXVII Encontro Nacional da Associação Portuguesa de Linguística, Lisboa, APL, 271284.

Folli, Raffaella/Harley, Heidi (2007), Causation, obligation and argument structure: On the nature of little «V», Linguistic Inquiry 38:2, 197-238.

Gonçalves, Anabela (1992), Para uma sintaxe dos verbos auxiliares em português europeu, dissertação de Mestrado, Faculdade de Letras da Universidade Lisboa.

Gonçalves, Anabela (1999), Predicados Complexos Verbais em Contextos de Infinitivo não Preposicionado do Português Europeu, tese de Doutoramento, Universidade de Lisboa.

Gonçalves, Anabela (2001), Predicados complexos com verbos causativos e perceptivos do Português europeu, in: Clara Nunes Correia/Anabela Gonçalves (edd.), Actas do XVI Encontro da Associação Portuguesa de Linguística, Lisboa, APL, 227-239.

Gonçalves, Anabela (2014), Temporal properties of infinitival domains in EP: Data from inflected infinitives in obligatory subject control contexts, comunicação convidada apresentada no First Seminar on Control and Finiteness at USP, Universidade de São Paulo, 30-31 de julho e 1 de agosto de 2014.

Gonçalves, Anabela/Duarte, Inês (2001), Construções Causativas em Português Europeu e em Português Brasileiro, in: Anabela Gonçalves/Clara Nunes Correia (edd.), Actas do XVI Encontro Nacional da Associação Portuguesa de Linguística, Lisboa, APL/Colibri, 657671.

Gonçalves, Anabela/Cunha, Luís Filipe/Silvano, Purificação (2010), Interpretação temporal dos domínios infinitivos na construção de reestruturação do Português europeu, in: Ana Maria Brito et al. (edd.). Textos Seleccionados do XXV Encontro Nacional da Associação Portuguesa de Linguística, Porto, APL, 435-447.

Gonçalves, Anabela/Santos, Ana Lúcia/Duarte, Inês (2014), (Pseudo-)Inflected infinitives and Control as Agree, in: Karen Lahousse/Stefania Marzo (edd.), Romance Languages and 
Linguistic Theory 2012. Selected papers from «Going Romance» Leuven 2012, Amsterdam/Philadelphia, Benjamins, 161-180.

Gonçalves, Perpétua (2015), Aspetos morfossintáticos da gramática do Português de Moçambique: a concordância nominal e verbal, Cuadernos de la ALFAL 7, 9-16.

Guasti, Maria Teresa (1993), Causative and perception verbs, Turin, Rosenberg and Sellier.

Guasti, Maria Teresa (1997), Romance causatives, in: Liliane Haegeman (ed.), The New Comparative Syntax, London/New York, Longman, 124-144.

Hernanz, Maria Lluïsa (1999), El infinitivo, in: Ignacio Bosque/Violeta Demonte (edd.), Gramática Descriptiva de la Lengua Española, Madrid, Espasa Calpe, 2197-2356.

Hornstein, Norbert/Martins, Ana Maria/Nunes, Jairo (2008), Perception and Causative Structures in English and European Portuguese: $\Phi$-feature Agreement and the Distribution of Bare and Prepositional Infinitives, Syntax 11:2, 205-229.

Kamp, Hans/Reyle, Uwe (1993), From Discourse to Logic - Introduction to Model theoretic Semantics of Natural Language, Formal Logic and Discourse Representation Theory, Dordrecht, Kluwer.

Kayne, Richard (1975), French Syntax: the Transformational Cycle, Cambridge MA, MIT Press (trad. francesa: Syntaxe du Français. Le cycle transformationnel, Paris, Éditions du Seuil, 1977).

Magro, Catarina (2005), Introdutores de orações infinitivas - o que diz a sintaxe dos clíticos, in: Inês Duarte/Isabel Leiria (edd.), Actas do XX Encontro Nacional da Associação Portuguesa de Linguística, Lisboa, Associação Portuguesa de Linguística, 649-664.

Martins, Ana Maria (1995), A Minimalist Approach to Clitic Climbing, in: Audra Dainora et al. (edd.), Papers from the 31st Regional Meeting of the Chicago Linguistic Society, Vol. 2: Parasession on Clitics, Chicago, Chicago Linguistic Society, 215-233.

Martins, Ana Maria (2004), Ambiguidade estrutural e mudança linguística: a emergência do infinitivo flexionado nas orações complemento de verbos causativos e perceptivos, in: Ana Maria Brito/Olívia Figueiredo/Clara Barros (edd.), Linguística Histórica e História da Língua Portuguesa. Actas do Encontro de Homenagem a Maria Helena Paiva, Porto, Secção de Linguística do Departamento de Estudos Portugueses e de Estudos Românicos da Fac. Letras Univ. Porto, 197-225.

Pereira, Sandra (2012), Protótipo de um glossário dos dialetos portugueses com informação sintática, tese de Doutoramento, Universidade de Lisboa.

Pereira, Sandra (2015), Causative and Perception Constructions in European Portuguese: the dialectal data, Dialectologia, Special Issue V, Syntactic Variation in Western European Languages, 53-80.

Raposo, Eduardo Paiva (1981), A construção de «União de Orações» na Gramática do Português, tese de Doutoramento, Universidade de Lisboa.

Raposo, Eduardo Paiva (1989), Prepositional Infinitival Constructions in European Portuguese, in: Osvaldo Jaeggli/Ken Safir (edd.). The Null Subject Parameter, Dordrecht, Kluwer, $277-$ 305.

Rizzi, Luigi (1976), Ristrutturazione, Revista di Grammatica Generativa 1, 1-54.

Rizzi, Luigi (1978), A Restructuring rule in Italian Syntax, in: Samuel J. Keyser (ed.) Recent Transformational Studies in European Languages, Cambridge MA, MIT Press, 113-158.

Rizzi, Luigi (1982), Issues in Italian Syntax, Dordrecht, Foris.

Roberts, Ian (1997), Restructuring, Head Movement, and Locality, Linguistic Inquiry 28, 423460.

Said Ali, Manuel (1908, $\left.{ }^{6} 1965\right)$, Dificuldades da Língua Portuguesa, Rio de Janeiro, Livraria Académica.

Said Ali, Manuel (1931, ${ }^{71971), ~ G r a m a ́ t i c a ~ H i s t o ́ r i c a ~ d a ~ L i ́ n g u a ~ P o r t u g u e s a, ~ R i o ~ d e ~ J a n e i r o, ~}$ Livraria Académica.

Sapir, Edward (1921), Language, Nova Iorque, Harcourt Brace Jovanovich.

Silva, Augusto Soares (1999), A Semântica de Deixar. Uma contribuição para a Abordagem Cognitiva em Semântica Lexical, Lisboa, Fundação Calouste Gulbenkian/MCT.

Soares Barbosa, Jerónimo (1822, $\left.{ }^{5} 1871\right)$, Grammatica Philosophica da Língua Portugueza ou Principios da Grammatica Geral Aplicada Aplicados à Nossa Linguagem, Lisboa, 
Typographia da Academia Real das Sciências.

Sousa, Xulio (2004), The expression of the causee in Galician, Portuguese, and Spanish, in: Elsa González-Álvarez/Andrew Rollings (edd.), Studies in contrastive linguistics, Santiago de Compostela, Universidade de Santiago de Compostela, 585-591.

Stowell, Tim (1982), The tense of the infinitives, Linguistic Inquiry 13, 561-570.

Svenonius, Peter (2008), Complex Predicates and the Functional Structure, Nordlyd 35:1, 4788.

Torrego, Esther (1998), The dependencies of objects, Cambridge MA, MIT Press.

Torrego, Esther (2010), Variability in the Case Patterns of Causative Formation in Romance and Its Implications, Linguistic Inquiry 41:3, 445-470.

Vasconcelos, Sofia (2013), O clítico SE: entre norma e variação, dissertação de Mestrado, Faculdade de Ciências Sociais e Humanas da Universidade Nova de Lisboa.

Villalba, Xavier (1992), Incorporation, Case and Economy. A Principled Approach to Causative Constructions, Catalan Working Papers in Linguistics, 345-389.

Wurmbrand, Suzanne (2001), Infinitives: Restructuring and clause structure, Berlin/New York, Mouton de Gruyter.

Wurmbrand, Suzanne (2004) Two types of restructuring - Lexical vs. functional, Lingua 114:8, 991-1014.

Wurmbrand, Suzanne (2006), Verb Clusters, Verb Raising, and Restructuring, in: Martin Everaert/Henk van Riemsdijk (edd.), The Blackwell Companion to Syntax, Oxford, Blackwell, 227-341.

Zubizarreta, Maria Luisa (1985), The relation between Morphophonology and morphosyntax and the case of Romance Causatives, Linguistic Inquiry 16, 247-289.

Zubizarreta, Maria Luisa (1987), Levels of Representation in the Lexicon and in the Syntax, Dordrecht, Foris. 